\title{
Studi Kasus: Descementocoles Corneal Ulcer pada Kucing Domestic Short Hair
}

\section{Case Study: Descementocoles Corneal Ulcer in Domestic Short Hair Cat}

\author{
Davinci Oswald Siahaan ${ }^{1}$, Nastiti Nur Patria Westri ${ }^{*}$, Ajeng Aeka \\ Nurmaningdyah ${ }^{1}$ \\ 1Program Studi Pendidikan Dokter Hewan Universitas Brawijaya, \\ Malang \\ *e-mail: nastiti.westri@gmail.com
}

\begin{abstract}
ABSTRAK
Penelitian ini membahas tentang Kornea Ulcer yang mencapai membran Descementocole pada kucing ras Domestik. Kornea Ulcer adalah kerusakan yang terjadi pada permukaan kornea di bagian epitel. Kornea Ulcer dibagi menjadi dua tipe menurut kedalamannya, yaitu Superficial corneal ulcer dan Deep corneal ulcer. Kucing Nancy diambil dari Pasar Karangploso Malang dengan gejala klinis mata kiri tampak berwarna keputihan. Gejala klinis yang terlihat adalah mata pada kucing Nancy terdapat selaput putih sehingga anterior chamber, iris dan pupil tidak terlihat. Mata kirikucing Nancy terdiagnosa Descementocoles corneal ulcer karena pada pemeriksaan fluorescent test mata bagian tengah sudah tidak dapat terwarnai oleh fluorescein. Kucing Nancy diberikan perlakuan berupa pemberian Cendo Genta $1 \%{ }^{\circledR}$ (Gentamycin), Cendo Mydriatil $0,5 \% ® \quad$ (Tropicamide), Cendo Protagenta ${ }^{\circledR}$ (Polyvinylpyrrolidone), dan Cendo Noncort ${ }^{\circledR}$ (Natrium Diclofenac).
\end{abstract}

Kata Kunci: Kucing, Kornea Ulcer, Descementocoles

\begin{abstract}
This study discusses the corneal ulcer that reaches the Descementocole membrane in domestic cats. Corneal ulcers are damage that occurs on the surface of the cornea in the epithelium. Corneal ulcers are divided into two types according to their depth, namely Superficial corneal ulcers and deep corneal ulcers. Nancy cat was taken from Pasar Karangploso Malang with clinical symptoms of a whitish left eye. The clinical symptoms that can be seen are the eyes in Nancy's cat have a white membrane so that the anterior chamber, iris and pupil are not visible. Nancy's cat's left eye was diagnosed with Descementocoles corneal ulcer because on a fluorescent test the middle eye could not be stained with fluorescein. Nancy's cats were treated in the form of giving Cendo Genta 1\%® (Gentamycin), Cendo Mydriatil $0.5 \% ®$ (Tropicamide), Cendo Protagenta ${ }^{\circledR}$ (Polyvinylpyrrolidone), and Cendo Noncort@ (Diclofenac sodium).
\end{abstract}

Key Words: Cat, Corneal Ulcer, Descementocoles 


\section{PENDAHULUAN}

Mata merupakan organ yang membantu fungsi sistem syaraf dalam menerima informasi tentang kondisi pada permukaan tubuh dan daerah sekitarnya. Mata merupakan organ yang paling sering mengalami kerusakan pada anjing maupun kucing. Kemampuan untuk melihat cahaya dan gerak merupakan aspek yang menentukan perspektif pengelihatan, ketajaman dan kedalaman penglihatan serta kemampuan untuk melihat warna dan bentuk. Kornea sendiri merupakan salah satu bagian mata yang mengalami kerusakan. Hal ini terjadi karena sebagian besar kornea terdiri dari protein sehingga rentan terhadap bahan kimia yang larut atau melewati protein. Kornea sangat tipis dan tebalnya kurang dari satu inci sehingga banyak penyakit yang dapat merusak ataupun menghancurkan membran tersebut. Kerusakan pada lapisan epitel membuat agen luar dapat menginvasi lapisan kornea yang lebih dalam dan dapat mengakibatkan Kornea Ulcer (Hartley,
Ulkus kornea atau corneal ulcer merupakan penykit yang sering terjadi pada anjing ataupun kucing. Ulkus kornea umumnya terjadi karena adanya trauuma atau benturan, selain itu ulkus kornea juga dapat terjadi akibat infeksi, alergi, trichiatis, enteropion dan kurangnya air mata. Infeksi sekunder pada ulkus kornea lebih banyak disebabkan karena bakteri gram negatif seperti Pseudomonas dibandingakn dengan bakteri gram positif seperti Staphylococcus dan Streptococcus. Karakteristik individu seperti usia, ras dan geografis daerah merupakan faktor yang erat kaitannya dengan penyakit okular (Stiles, 2014).

\section{STUDI KASUS}

\section{Anamnesa}

Kucing Nancy diambil dari Pasar Karangploso Malang dengan gejala klinis mata kiri tampak berwarna keputihan. Gejala klinis yang terlihat adalah mata pada kucing Nancy terdapat selaput putih sehingga anterior chamber, iris dan pupil tidak terlihat. 2010). 


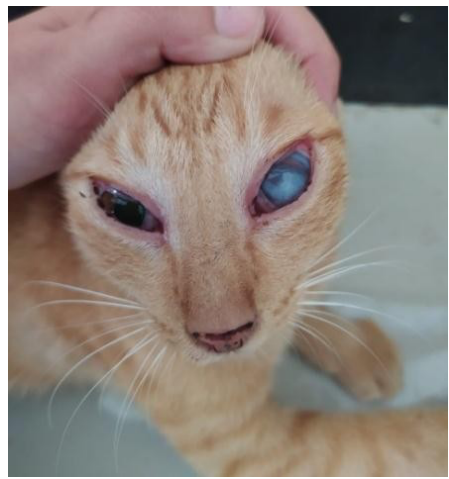

Gambar 1. Kondisi Awal Kucing Nancy

\section{Pemeriksaan Fisik}

Temuan klinis yang ditemukan pada kucing Nancy diantaranya adalah mata sinister terdapat selaput berwarna putih dengan kondisi tubuh $2 / 5$ dan padaemeriksaan fisik lainnya tidak ditemukan adanya kelainan.

\section{Diagnosa dan Prognosa}

Berdasarkan hasil anamnesa, pemeriksaan fisisk dan pemeriksaan penunjang yang telah dilakukan pada kucing Nancy.Diagnosa yang dapat diberikan pada kucing Nancy adalah Descementocoles Corneal Ulcer dengan prognosa Dubius Fausta.

\section{Terapi}

Pada kasus kucing Nancy terjadideep corneal ulcer yang merusak sebagian lapisan mata dan mengalamiperforasi sampai ke lapisan endhotel namun hanya sebagian sehingga kemungkinan mata kembali normal masih mungkin. Sehingga diberikanobat-obatan yang bersifat topical saja seperti Cendo Genta $1 \% \quad ®$ (Gentamycin), Cendo Mydriatil 1\% $®$ (Tropicamide), Cendo Noncort ${ }^{\circledR}$ (natrium diclofenac), dan Cendo Progenta ${ }^{\circledR}$ (Polyvinylpyrrolidone).

\section{PEMBAHASAN}

Kucing Nancy memiliki gejala klinis terdapat selaput berwarna putih pada mata sinister. Dari hasil pemeriksaan penunjangng dengan menggunakan Fluorescein Test dan Schirmer Test kucing Nancy didiagnosa mengalami Desmentocoles Corneal Ulcer dengan hasil Fluorescein Test positif. Kornea merupakan struktur transparan yang menyerupai kubah, merupakan pembungkus dari iris dan pupil berfungsi membantu memfokuskan cahaya. Kornea tersusun atas 3 lapisan yaitu lapisan epitel, stroma, dan membrane descemen (Foster et al, 2009).

Ulkus kornea adalah kerusakan yang 
terjadi pada permukaan kornea di bagian epitel. Ulkus kornea biasanya disebabkan oleh trauma pada kornea baik karena infeksi (contohnya Feline herpes virus), kurangnya sekresi air mata (contohnya keratoconjuntivitis sicca), dan kelainan rambut mata (contohnya enteropion). (Najafi et al., 2014). Ulkus kornea biasanya ditandai dengan gejala sakit yang sangat pada daerah mata dikarenakan permukaan kornea dipenuhi oleh sarafsaraf reseptor, fotopobia dikarenakan terjadi peradangan yang menyebabkan tidak nyaman di mata, menyipitkan mata, konjungtiva dan sklera memerah serta warna cornea menjadi keruh keputihan (Schoster, 2009).

Ulkus kornea dibagi menjadi dua tipe menurut kedalamannya, yaitu

1. Superficial corneal ulcer: ulkus kornea yang terjadi pada permukaan kornea saja. Biasanya dapat sembuh cepat dalam beberapa hari.

Indolent corneal ulcer: ulkus kornea yang mengalami persembuhan yang lambat. Penyebab lamanya persembuhan adalah adanya kelainan pada epitel membran (epithelial basement membran disease)

2. Deep corneal ulcer: ulkus kornea yang terjadi pada setengah atau lebih ketebalan dari kornea. Biasanya memerlukan waktu beberapa minggu untuk sembuh.

Descementocoles: deep corneal ulcer yang mencapai membran descement. Biasanya disebabkan oleh infeksi sekunder, mata kering dan peradangan.

Penyebab corneal ulcer pada umumnya bisa karena adanya trauma yang menyebabkan luka pada lapisan kornea, infeksi bakteri sepeti chlamydia $s p$. Dan infeksi virus seperti virus herpes dan calici. Infeksi chlamidya sp., virus herpes dan calici akan menghancurkan epitel yang ada di bagian subkonjungtiva lalu menyebar ke epitel (Laguna et al., 2015). Pada kasus kucing Nancy tidak diketahuinya sejarah perjalanan penyakit karena kucing Nancy merupakan hewan rescue sehingga sulit untuk diketahui penyebab dari corneal ulcer 
tersebut.

Pada keadaan kronis kornea ulser dapat berkembang menjadi corneal squestrum.Corneal squestrum merupakan suatu kondisi dimana sel-sel pada kornea yang telah mengalami kerusakan berubah warna menjadi putih kekuningan hingga putih kecoklatan. Pada kucing yang mengalami keadaan ini rasa nyeri sudah tidak ada kan tetapi keadaan dapat berlanjut karena corneal squestrum akan menginvasi bagian kornea yang masih sehat sehingga mata dapat tertutup oleh lapisan yang dibentuk oleh corneal squestrum yang menyebabkan penglihatan mengalami gangguan (Hanninen, 2014). Tindakan terapi yang dapat dilakukan adalah dengan menggunakan antibiotik dan tindakan operasi (Pumphrey et al., 2019).

Gentamycin merupakan jenis antibiotik golongan aminoglikosida dan memiliki efek bakterisidal yang sangat baik untuk infeksi bakteri gram negatif, tetapi beberapa bakteri Staphylococcusdan Streptococcus yang sering menginfeksi pada kasus corneal ulcer juga efektif digunakan. Pada kasus ini digunakan Cendo Genta 1\% ${ }^{\circledR}$ untuk mencegah dan mengobati infeksi yang terjadi pada kornea kucing. Gentamycin menghambat sintesis protein dari bakteri dengan cara berikatan dengan ribosom prokariotik subunit 30 s dan 50s. Gentamycin sendiri memiliki absorbsi yang kurang baik jika diberikan secara peroral karena absorbsi gentamycin pada saluran cerna sangat rendah (Ramsey, 2017).

Tropicamide merupakan antikolinergik yang bekerja dengan cara menghambat asetilkolin pada sphincter dan ciliary body iris, yang meyebabkan mydriasis (pupil dilatasi). Tropicamide menyebabkan midriasis dan cycloplegia, namun lebih banyak berfungsi sebagai midriasis. Tropicamide memiliki onset yang lebih cepat (midriasis maksimum dalam 15-30 menit) aksi dan durasiaksi yang lebih pendek (pupil kembali normal dalam 6-12 jam pada kebanyakan hewan) di banding dengan atropine, dan memiliki dosis pada anjing kucing 1 tetes tiap mata dan dapat 
diulangi 20-30 menit setelahnya. Pemilihan

cendo mydriatil dibandingkan dengan atropin dikarenakan atropin memiliki rasa yang pahit sehingga khususnya untuk kucing mudah mengalami hipersalivasi. Pada mata, tropicamide bekerja menghambat respon otot sfingter iris dan otot akomodasi badan ciliar terhadap perangsangan kolinergik (Ramsey, 2017). Polyvinylpyrrolidone merupakan salah satu jenis obat yang berisi larutan isotonic, dan memiliki sifat $\mathrm{pH}$ Buffer yang berfungsi sebagai lubrikan untuk mata kering dan iritasi mata terkait dengan sindrom mata kering. Sering juga digunakan pada anjing/kucing yang mengalami keratoconjunctivitis sicca. Polyvinylpyrrolidone juga berfungsi untuk lubrikan mata pada kasus hewan yang produksi air matanya menurun (Plumb, 2008).

Natrium diclofenac adalah obat NSAID atau Non Steroid Anti Inflammatory Drug yang digunakan untuk radang serta sebagai analgesik pada mata. Obat ini menginduksi lipase inhibitor fosfolipase A2 atau lipokortin dan menghambat pelepasan asam arakidoat sehingga menekan aktivitas prostaglandin, leukotrien dan mediator inflamasi lainnya. Dosis obat ini adalah 1 hingga 2 tetes yang dapat diberikan 2 hingga 4 kali sehari dengan pengurangan frekuensi jika kondisi sudah terkendali. Pada penderita corneal ulcer tidak diperbolehkan pemberian antiinflamasi berjenis steroid karena dapat memperparah kondisi ulcer (Plumb, 2008).

\section{KESIMPULAN}

Pada kasuskucing Nancy mengalamikelainan pada matakirinya yakni terdapat selaput berwarna putih. Mata kirikucing Nancy terdiagnosa Descementocoles corneal ulcer karena pada pemeriksaan fluorescent test mata bagian tengah sudah tidak dapat terwarnai oleh fluorescein. Terapi yang dilakukan adalah pemberian elizabert collar untuk meminimalisir kucing Nancy menggaruk bagian mata dan pemberian obat tetes mata seperti cendogenta $1 \% ®$ sebagai antibiotik, 
cendo mydriatil $0,5 \% ®$ untuk midriasis, cendo protagenta sebagai pengganti air mata karena hasil Shirmer Test kucing Nancy menunjukkan mata kiri kering dengan hasil $5 \mathrm{~mm} /$ menit dari angka normal $15 \mathrm{~mm} /$ menit dan cendo noncort ${ }^{\circledR}$ yang berfungsi sebagai antiinflamasi nonsteroid.

\section{DAFTAR PUSTAKA}

Foster, P.J., Wong, T.T., Wong, T.Y., Crowston, J.G., Fong, C.W. and Aung, T., 2009. The relationshipof intraocular pressure with age, systolic blood pressure, and central corneal thickness in an Asian population. Investigative ophthalmology $\mathcal{E}$ visual science, 50(9), pp.4097-4102

Hartley, C., 2010. Aetiology of Corneal ulcers: Assume FHV-1 unless proven otherwise.

Hanninen, O., 2014. Feline corneal sequestra: Morphological characterisation of normal and sequestered cornea.Veterinary feline Helsinki

Medicine University of

Laguna, F., Leiva, M., Costa, D., Lacerda, R. and Peña Gimenez, T., 2015. Corneal grafting for the treatment of feline corneal sequestrum: a retrospective study of 18 eyes (13 cats). Veterinary ophthalmology, 18(4), pp.291296.

Najafi, H., Madadgar, O., Jamshidi, S., Langeroudi, A.G. and Lemraski, M.D., 2014. Molecular and clinical study on prevalence of feline herpesvirus type 1 and calicivirus in correlation with feline leukemia and immunodeficiency viruses.

In Veterinary Research Forum (Vol. 5, No. 4, p. 255). Faculty of Veterinary Medicine, Urmia University, Urmia, Iran.

Plumb, Donald C. 2008. Plumb's Veterinary Drugs Handbook Sixth Edition. South State Avenue Ames, Iowa: Blackwell Publishing Professional

Pumphrey, S.A., Desai, S.J. and Pizzirani, S., 2019. Use of cyanoacrylate adhesive in the surgical management of feline corneal sequestrum: 16 cases (2011-2018). Veterinary Ophthalmology, 22(6), pp.859-863.

Ramsey, I., 2017. BSAVA Small Animal Formulary, 9th edn-Part A: Canine and Feline.

Schoster. 2009. Complicated Corneal Ulcers Microbial Keratitis. University of Wisconsin USA

Stiles, J., 2014. Ocular manifestations of feline viral diseases. The Veterinary Journal, 201(2), pp.166-173. 